Sosyo

Ekonomi

\title{
Türkiye'de Vergi Denetim Sistemi ve Sistemin Aksaklıklarının Değerlendirilmesi
}

Zuhal ERGEN

zergen@cu.edu.tr
Leman KILINÇKAYA

leman.kerioz@vdk.gov.tr

\section{Tax Audit System in Turkey and Evaluating Disruptions of the System}

\begin{abstract}
In Countries where the statement basis is valid, auditing taxpayers'transactions is a must for the system. Considering their contributions to the public pudget and substantiation of the sovereignty power of the government, tax auditings have major importance. However, the effectiveness of auditing activities depends on many institutional and structural factors. In this manner, citizens and government should bear important duties. In Turkish Tax System, with Decree Law No. 646 some promising but "inadequate in implementation" efforts made like transition to automation of the tax administration and raising the awareness of the taxpayer. A strong budget derives from a powerful tax system; the tax system originates from an effective and efficient tax auditing system. This study evaluates disruptions taxpayers faced during the tax auditing process.
\end{abstract}

Keywords : Tax Audit System, Taxpayer, Taxpayer Rights.

JEL Classification Codes : $\mathrm{H} 2$.

\section{Özet}

Beyan esasının geçerli olduğu ülkelerde mükelleflerin vergisel işlemlerinin denetlenmesi, sistemin olmazsa olmazlarındandır. Vergi denetimleri; bütçeye olan katkıları, devletin hükümranlık gücünün ispatı vb. nedenlerle büyük öneme sahiptirler. Ancak denetim faaliyetlerinin etkinliği birçok kurumsal ve yapısal etkene bağlıdır. Bu konuda vatandaşlara ve devlete büyük görevler düşmektedir. Türk Vergi Sisteminde 646 Sayılı Kanun Hükmünde Kararname ile vergi idarelerinde otomasyona geçilmesi, mükelleflerin bilinçlendirilmesi gibi alanlarda umut verici çalışmalar yapılsa da bu uygulamalar yetersiz kalmaktadır. Güçlü bir bütçe, güçlü bir vergi sisteminden, güçlü bir vergi sistemi ise etkin ve verimli bir vergi denetim sisteminden geçer. Çalışma mükelleflerin vergi denetimi esnasında karşılaştıkları aksaklıkları değerlendirmektedir. 
Zuhal ERGEN \& Leman KILINÇKAYA

282 


\section{Giriş}

Vergi denetimi; vergi mükelleflerince vergiye tabi iktisadi faaliyetle ilgili beyanın, ödenecek vergi miktarının ve vergi idaresinin işleyişinin mevcut vergi hükümlerine uygunluğunu araştırmaya yönelik, tarafsızca kanıt toplayan ve kanıtları değerlendiren sistematik bir süreçtir (Binbirkaya, 2006: 13). Vergi denetim süreci vergisel işlemler yapılırken vergi kanunlarına riayet edilip edilmediği, yapılan hata ve noksanların tespiti ve cezalandırılması aşamalarından oluşur. Vergi denetimi devletin asli gelir kaynağı olan vergilerin toplanması açısından bir caydırıcılık unsuruna sahip olması ve vergi incelemeleri sonucu önerilen tarhiyat ve cezalar aracılığıyla da bir tahsilât aracı olması nedeniyle büyük önem taşır.

Vergi denetimi her çağda devletlerin ilgi gösterdikleri bir alan olmuştur. Devletler başta hükümranlık güçlerinin sağlamlaştırılması ve finansman ihtiyacının karşılanması gibi nedenlerden dolayı bu alana ilgi göstermişlerdir. Kamu varlık ve faaliyetlerinin denetiminin temelini oluşturduğu söylenen bir arkeolojik çalışmaya göre, eski Mezopotamya'da hüküm süren kralların, kraliyet tahıl ambarlarının sayımını yapmak ve buradaki görevlileri kontrol etmek için kâtiplerine yetki verdikleri ortaya çıkmıştır (Khan'dan Aktaran Özer, 1997: 5). 1930'lu yıllardan itibaren ise finansal tabloların doğruluk ve dürüstlüğü hakkında bir görüş oluşturma amacıyla denetimin tarafları değişerek, ortaklar işletmeye borç verenler, devlet, sendikalar, parlamento, tüketiciler v. s. gruplar denetimin tarafları olmuşlardır (Güredin, 2007). Her geçen gün denetimin tarafları artmış, vergi denetimi günümüzde sadece vergi kayıp ve kaçaklarını tespit etme aracı olmaktan çıkmış ekonomik birimlerin de ilgilendiği bir alan haline gelmiştir. Örneğin; vergisel yönden sakıncalı faaliyetleri nedeniyle vergi denetimi sonucu özel esaslara tabi olan bir şirketle, piyasadaki diğer şirketler ticari faaliyette bulunmakta tereddüt etmektedirler. İşte bu gibi nedenlerle vergi denetimi gerek devlet, gerekse diğer ekonomik birimler açısından büyük önem arz etmekte ve vergi denetim sisteminde yer alan aksaklıklar piyasada adeta bir domino etkisi yaratmaktadır.

Etkin bir vergi denetim sisteminin oluşturulması birçok etkene bağlıdır. Sadece kanun çıkarmak bu sistemde yer alan aksaklıkları gidermeye yetmeyecektir. Bu alanda sosyal içerikli çalışmalar da yapılması gerekir. Bu anlamda vergi ahlakı ve vergi bilincinin vatandaşlara yerleştirilmesi çok önemlidir. Ayrıca denetim şekli de denetimin etkinliği açısından büyük rol oynar. Ülkemizde vergi denetiminin usulsüzlükler yapıldıktan sonra adeta bir tespit raporu şeklinde olması etkinliği azaltan unsurlardandır. Bu durum vatandaşların işlemlerini kayıtlı yaparak cezalandırıldıkları hissine kapılmalarına neden olur. Vatandaşlar vergisel kurallara uymak yerine işlemlerini nasıl kayıt dışı hale getirebileceklerine kafa yorar. Vergi denetim sisteminde etkinliğe ulaşılmasını engelleyen bir diğer unsur da kurumsal nedenlerdir. Vergi denetimiyle uğraşan personelin özlük sıkıntıları çekmesi, bu kurumun bürokratların çıkar çatışmalarıyla yıpranması hem denetim 
personelinin motivasyonunu hem de vatandaşın bu kuruma olan güvenini sarsmaktadır. Çalışmamızda bu aksaklıkları, Türkiye'de vergi denetim sisteminin nasıl olduğunu ve önemini anlatmaya çalışırken, vergi denetim sisteminin en ilgi çekici ayağı olan vergi incelemesi üzerinde duracağız.

\section{Türkiye'de Vergi Denetim Sistemi}

Geniş anlamıyla vergi denetimi kavramı, vergi mükelleflerinin beyanlarının doğruluğunun incelenmesini (vergi incelemesi) ve vergi idaresinin merkez ve taşra teşkilatının iç denetime tabi tutulması (teftiş) ile vergi idaresi personelinin gerektiğinde soruşturmalarının yapılmasını kapsamaktadır.

Ülkemizde hukuki açıdan vergi denetim türleri üçe ayrılmaktadır. Bunlar yoklama, iç denetim ve vergi incelemesidir.

Yoklama: Mükelleflerin ve mükellefiyetle ilgili maddi olayların, kayıtların ve mevzuların vergi idaresinin yetkili memurlarınca araştırılması ve tespit edilmesidir. VUK'un 127. maddesinde yoklamanın amacının mükellefleri ve mükellefiyetle ilgili maddî olayları, kayıtları ve mevzuları araştırmak ve tespit etmek olduğu belirtilmiştir. Yoklama sadece mükelleflerin işe başlama, işi bırakma ve iş değişikliği ile sınırlı olmayıp yoklamada esas amaç vergiyi doğuran olay ile ilgili birçok hususu tespit etmektir. Yoklama müessesesi henüz mükellefiyetini tesis ettirmemiş kişilerin ve vergilendirilmeyen kaynakların ortaya çıkarılmasına ve dolayısıyla vergi gelirlerinin arttırılmasına katkı sağlaması, vergi kaçıranların ve vergilendirilmemiş kaynakların tespit edilmesine yardımcı olması sayesinde; ticari rekabetin ve sosyal adaletin sağlanmasına da yardımcı olur.

VUK'un 130. maddesine göre; yoklama ilgiliye haber verilmeksizin istenildiği zaman yapılabilmektedir. Diğer bir deyişle, yoklama, yılın herhangi bir gününde, belli bir mevsim, gün, ay saptanmaksızın yapılabilmektedir. Yoklama ile esasen mükelleflerin vergi dairesi içerisinde kâğıt üzerinde gözüken faaliyetlerinin gerçekliği ve fiili durumu tespit edilmektedir. Yoklama özellikle sahte fatura düzenlemek üzere tesis edilmiş mükellefiyetlerin tespiti açısından önem arz etmektedir. Örneğin resmi kayıtlarda reklamcı olarak görünen bir işletmeye yoklama yapıldığında işletmede herhangi bir baskı makinesi ya da çalışan bulunmadığı tespiti yoklama sayesinde yapılmakta ve bu veri mükellefi sahte belge düzenleyicisi olarak ilan ederken vergi inceleme elemanlarına önemli bir kanıt oluşturmaktadır. Bu yönüyle yoklama vergi incelemelerini de kolaylaştırmaktadır.

VUK'un 128. maddesine göre yoklama; vergi dairesi müdürleri, yoklama memurları, yetkili makamlar tarafından yoklama işi ile görevlendirilenler, vergi incelenmesine yetkili olanlar ve gelir uzmanları tarafından yapılır. Yoklama belli bir anda mükellefin fiili durumunu tespit ettiğinden, bu tespiti yapacak olan memurların, tarafsız ve 
gerçek durumu anlatan tespitler yapmaları çok önemlidir. $\mathrm{Bu}$ nedenle yoklama işiyle görevlendirilenlerin eğitimi ve koşulları büyük önem arz etmektedir.

İç Denetim: Vergi idaresi çalışanlarının vergi sisteminde öngörülen kurallara uygun davranıp davranmadıklarını saptama, uygulamada yapılan yanlışlıkların düzeltilmesi ve bu yanlışlıkları yaratan nedenlerin tasfiyesini amaçlayan çalışmalar bütünüdür. İç denetim teftiş ve soruşturma yetkisine haiz memurlarca yapılır.

Vergi denetiminin önemli bir aracı olan iç denetim sayesinde yasaların mükelleflere eşit olarak uygulanması ve personelin doğru işlem yapmaya yönlendirilmesi sağlanır. Böylece verginin gerçeğe uygun alınmasına katkıda bulunulmuş olunur.

Vergi İncelemesi: Vergi denetimi ile ilgili olarak Maliye Bakanlığı, bünyesinde Vergi Denetim Kurulu teşkil edilmiş olup, kurul bünyesinde görevlendirilen vergi müfettişleri "vergi incelemesi", "teftiş" ve "soruşturma" yetkilerine haizdirler. Bu yetkilerden ekonomik açıdan ve mükellefler açısından en ilgi çekici olan ise vergi incelemesi olmuştur.

Vergi incelemesi, beyanların ve ödenmesi gereken vergilerin doğruluğunu sağlamak amacıyla yükümlünün defter kayıtları, belgeleri ve envanteri üzerinde yapılan derinlemesine bir araştırmadır (Öncel, Kumrulu, Çağan, 2008: 100). Başka bir deyişle; vergi incelemesi, vergi mükellef ve sorumlularının vergi ile ilgili işlemlerinin, yapılmasından veya yapılmaları gereken aşamadan sonra, vergi idaresinin yetkili elemanlarınca denetlenmesidir (Candan, 2001: 153). Vergi incelemesi 5 yıllık tarh zamanaşımı süresi sonuna kadar, önceden bildirilmeksizin her zaman yapılabilir.

10 Temmuz 2011 tarihli Resmi Gazete'de yayımlanarak yürürlüğe giren 646 sayılı "Vergi Denetim Kurulu Başkanlığının Kurulması Amacıyla Bazı Kanun ve Kanun Hükmünde kararnamelerde Değişiklik Yapılmasına Dair Kanun Hükmünde Kararname" ile "Vergi Denetim Kurulu Başkanlığg”" kurulmuştur. Sözü edilen kararnameyle vergi denetimini gerçekleştirecek vergi müfettişlerinin yer aldığı farklı gruplar oluşturulmuş ve hangi grupta yer alan vergi müfettişlerinin küçük ve orta ölçekli mükellefleri, hangi grupta yer alan vergi müfettişlerinin diğer mükellefleri inceleyecekleri hükme bağlanmıştır.

VDK'nın kurulmasından önce Maliye Teftiş Kurulu, Hesap Uzmanları Kurulu, Gelir İdaresi Başkanlığı'nın merkezi denetim birimi Gelirler Kontrolörleri Başkanlığı ve taşra denetim birimi Vergi Denetmenleri Büro Başkanlıklarından oluşan çoklu bir denetim yapısı söz konusuydu. Ülkemizde Maliye Bakanlığının fonksiyonlarının artması ve yaygınlaşması gerekçesiyle oluşturulan aynı işi yaptığı halde farklı işleyişlere sahip olan 
denetim birimleri, bir yandan mükerrer denetime ve kaynak israfina, diğer yandan da denetim kargaşasına ve denetim birimleri arasında koordinasyonsuzluğa sebep olmaktayd ${ }^{1}$. Yeterli teknik bilgiye sahip olmayan mükellefler denetim birimleri arasındaki farklılığı anlamakta güçlük çekmekteydi. Merkezi denetim birimleri büyük mükellefleri inceleyecekleri gerekçesiyle turnelere gittkleri yerdeki büyük mükellefleri tekrar tekrar incelemeye almakta bu durum mükellefleri adeta devlete küstürmekteydi. Üç merkezi denetim birimi tarafindan da sırf büyük ölçekli olduğu gerekçesiyle mükelleflerin mükerrer denetimlere tabi tutulması söz konusuydu. Hala tam anlamıyla giderilememiş olsa da aynı işi yapan denetim elemanları arasındaki özlük hakları farklılığı denetim elemanlarının motivasyonunu bozmaktaydı. Ayrica denetim birimleri arasında yer alan kast sistemi ve çok başlılık denetim birimleri arasında koordinasyon bozukluğuna ve vergi denetiminde etkinsizliğe neden olmaktaydı. Oysa Dokuzuncu Kalkınma Planı Vergi İhtisas Komisyonu Raporunda da yer verildiği üzere vergi denetiminin etkinsizliği, kayıt dışı ekonomiyi besleyen faktörlerden biridir. Yine aynı raporda vergi idaresinin denetim etkinliğinin güçlendirilmesi gerektiği görüşüne yer verilmiştir.

646 Sayılı Kanun Hükmünde Kararname ile yapılan düzenlemeyle, Vergi Denetim Kuruluna verilen görevlerin yerine getirilmesinde, Bakan onayı ile doğrudan Vergi Denetim Kurulu Başkanlığına bağlı olmak üzere:
a) Küçük ve Orta Ölçekli Mükellefler Grup Başkanlığı,
b) Büyük Ölçekli Mükellefler Grup Başkanlığg,
c) Organize Vergi Kaçakçılı̆̆ı ile Mücadele Grup Başkanlığı,
d) Örtülü Sermaye, Transfer Fiyatlandırması ve Yurtdışı Kazançlar Grup Başkanlı̆̆

olmak üzere dört grup başkanlığı kurulması öngörülmüş̧ür. Vergi Denetim Kurulu bu dört grup başkanlığında çalışan vergi müfettişleri aracilığıyla "Çağdaş denetim tekniklerini kullanarak risk odakll vergi incelemeleri yapmak, vergi kayıp ve kaçağına neden olan kayıt dişı ekonomiyi en aza indirmek, mükelleflerin vergiye gönüllü uyumunu artırmak, idarenin etkin ve hukuka uygun işleyişinin sağlanması amactyla teftiş ve soruşturma faaliyetlerini yürütmek, maliye politikalarının oluşturulmasına yönelik hukuki düzenlemelerin hazırlanmasina katkıda bulunma" misyonuyla faaliyetini sürdürmektedir.

Vergi Denetim Kurulu bünyesinde 01.01.2013 itibariyle 14.243 vergi müfettişi ve vergi müfettiş yardımcısı görev yapmaktadır. Aşağıdaki tabloda ise 2012 yılı sonu

1 Mesut HASTÜRK, Türkiye'de Vergi Denetiminin Etkinliğinin Incelenmesi ve Değerlendirilmesi, $2010: 88$. 
itibariyle mükellef sayıları yer almaktadır. Buna göre müfettiş başına (6.898.290/14.243) yaklaşık 484 mükellef düşmektedir.

Tablo: 1

2012 Yılsonu İtibariyle Vergi Mükellefi Sayıları

\begin{tabular}{|l|r|}
\hline GELİR VERGİSİ FAAL MÜKELLEF SAYILARI & 1.760 .785 \\
\hline GELİR STOPAJ FAAL MÜKELLEF SAYISI & 2.433 .590 \\
\hline GMSİ FAAL MÜKELLEF SAYISI & 1.336 .632 \\
\hline BASİT USULDE VERGILENDİIILEN FAAL MÜKELLEF SAYISI & 705.093 \\
\hline KURUMLAR VERGİSI FAAL MÜKELLEF SAYILARI & 662.190 \\
\hline TOPLAM & 6.898 .290 \\
\hline
\end{tabular}

Kaynak: <http://www.gib.gov.tr> internet sitesinin istatistikler bölümünde yer alan verilerden faydalanılarak hazırlanmiştır.

Vergi müfettişleri inceleme yetkisini kanunlardan alırlar, nitekim VUK'un 134148. maddeleri vergi incelemeleriyle ilgili düzenlemeleri içerir. VUK'un 135 maddesine göre Vergi Íncelemesi; vergi müfettişleri, vergi müfettiş yardımcıları, ilin en büyük mal müdürü veya vergi dairesi müdürleri tarafından yapılır. Gelir İdaresi Başkanlığının merkez ve taşra teşkilatında müdür kadrolarında görev yapanlar her hal ve takdirde vergi inceleme yetkisine haizdir. VUK'un 75. maddesi uyarınca, takdir komisyonları görevlerini yerine getirirken inceleme yetkisine sahiptir. Ancak vergi incelemesi yapma görevi vergi müfettişlerinin asli görevi iken kanun maddesinde sayılan diğer birimlerin görevlerinin tamamlayıcı bir yetkisidir. $\mathrm{Bu}$ nedenle vergi incelemelerinin büyük çoğunluğu vergi müfettişleri ve vergi müfettiş yardımcıları tarafından yapılır. Vergi incelemelerinde Uyulacak Usul ve Esaslar Hakkında Yönetmeliği ise vergi incelemesini düzenleyen kanun maddelerinin yürürlüğü konusunda yol gösterir.

\section{Türk Vergi Denetim Sisteminin Mükellef Açısından Değerlendirilmesi}

Ülkemizde vergi incelemesinin kurumsal özelliklerinin yanında, vergi incelemesine mükellef hak ve yükümlülükleri açısından da bakmakta fayda vardır. VUK'un 134. maddesinde, vergi incelemesinden maksadın, ödenmesi gereken vergilerin doğruluğunu araştırmak, tespit etmek ve sağlamak olduğu belirtilmiştir. Vergi incelemesi yapılırken mükellefin bir takım haklarının gözetilmesi gerekmektedir. Bu hakların gözetilmesi vergi idaresinin mükellefine karşı yükümlülügüüdür. Bunun yanı sıra mükellefin de vergi incelemesinin doğru bir şekilde gerçekleşmesi için vergi mevzuatından doğan yükümlülüklerini yerine getirmesi gerekmektedir.

Türk Vergi Sistemi ağırlıklı olarak beyana dayalıdır. Beyana dayalı vergi sisteminin en belirgin özelliği mükellefleri ön plana çıkarması ve beyanlarını doğru kabul etmesidir. Bireyler belirli yöntemlerle belirli sürelerde önce gelirlerini belirleyecek, sonra da bunu ilgili vergi idaresine beyan edecektir. Kamu otoritesi önceden ne gelir 
saptanmasında ne de beyanda rol almazken günümüzde vergi idaresi olarak; tarh, tahakkuk ve tahsil aşamalarında ağırlığını hissettirmektedir. Bu sistemin temel sonucu mükelleflerin vergi incelemesine tabi olmasıdır. Etkin bir vergi incelemesi ancak tarafların hak ve yükümlülüklerine uygun davranmalarıyla mümkündür. Vergi inceleme sürecinde bir tarafın hakları diğer tarafın yükümlülükleridir. İdare kendi yükümlülüklerini yerine getirirse mükellef haklarına uygun davranmış olacak, mükellef yükümlülüklerini yerine getirirse idarenin haklarına uygun davranmış olacaktır. Vergi inceleme sürecinde mükelleflerin sahip oldukları haklar ve riayet etmek zorunda oldukları yükümlülüklerinden bahsedeceğiz. Böylece idarenin hak ve yükümlülüklerini de belirtmiş olacağız.

\subsection{Vergi İnceleme Sürecinde Mükellefin Hakları}

Mükelleflerin, bir kısmı VUK' da bir kısmı ise diğer kanunlarda yer alan hakları (aynı zamanda idarenin de yükümlülükleri) aşağıdaki gibidir:

İnceleme Elemanının Kimliğini Görme Hakkı: Bu hak VUK'un 136. maddesinde "hüviyet ibrazı" başlığı altında düzenlenmiştir. Mükellef, inceleme için gelen inceleme elemanının kimliğine görme hakkına sahiptir. Buna göre vergi incelemesi yapanların yanlarında memuriyet sıfatlarını ve inceleme yetkisini gösteren fotoğraflı resmi bir vesika bulundurma ve gittikleri yerde işe başlamadan evvel bu vesikayı ilgililere gösterme zorunlulukları vardır. $\mathrm{Bu}$ hak sayesinde hem mükellefler hem de idare dolandırıcılık vakalarına maruz kalmamış olur ve idareye güveni sarsılmaz.

İncelemenin Kendi İşyerinde Yapılmasını İsteme Hakkı: VUK’un 139. maddede açıklanmıştır. Buna göre vergi incelemesi esas itibariyle incelemeye tabi olanın işyerinde yapılır. Ancak iş yerinin müsait olmaması, ölüm, işin terk edilmesi gibi zaruri sebeplerle incelemenin yerinde yapılması imkânsız olur veya mükellef ve vergi sorumluları isterlerse inceleme dairede yapılabilir. Burada seçimlik hak mükellefe aittir. Böylece incelemenin dairede yapılmasını istemek de mükellef için bir haktır.

Ínceleme Konusunu Öğrenme Hakkı: VUK'un 140. maddesinde “incelemede uyulacak esaslar" başlı̆̆ında anlatılmıştır. Buna göre vergi incelemesi yapanların incelemeye tabi olana, bunun mevzuunu (konusunu) işe başlamadan evvel açık olarak izah etmeleri mecburidir. Bu hak çok önemlidir. Mükelleflerin tedirgin edilmemesi ve endişeye düşürülmemesi için gerekli bilgilendirmenin yapılması gerekir.

İşyerinde Yapılan İnceleme de Mesai Saatleri Dışında İnceleme Yapılmamasını İsteme Hakkı: VUK'un 140. maddesine göre inceleme yapanlar nezdinde inceleme yapılanın muvafakati olmadıkça resmi çalışma saatleri dışında inceleme yapamazlar veya buna devam edemezler. Tutanak düzenlenmesi ve inceleme ile ilgili emniyet tedbirlerinin alınması bu hükmün istisnasını oluştursa da, bu gibi tedbirlerin, 
incelemelerin yapıldı̆̆ı yerdeki faaliyeti sekteye uğratmayacak şekilde yapılması zorunludur.

İncelemenin, İşyerinin Faaliyetini Engellememesini İsteme Hakkı: VUK'un 140. maddesine göre işyerinde yapılan incelemede gerekli güvenlik tedbirlerinin alınacağ ancak bunun işyerinin faaliyetini aksatmayacağı hükme bağlanmıştır.

İnceleme Bittiğinde, Bunun Yapıldığına Dair Belge İsteme Hakkı: VUK'un 140. maddesine göre inceleme bitince, bunun yapıldığını gösteren bir vesikanın nezdinde inceleme yapilana verilmesi zorunludur. İnceleme sonucunda, vergi salma ve/veya ceza kesme söz konusu ise bir rapor yazılmaktadır. Bu rapor da VUK'un 35. ve 366. maddeleri gereğince ihbarnamenin ekinde tebliğ edilmektedir. Ancak vergi tarhiyatı yahut ceza gerektirecek herhangi bir husus yoksa mükellefin elinde inceleme yapıldığına dair bir belge olması açısından bu tutanağın verilmesi zorunludur.

Tutanaktan Bir Nüsha Alma Hakkı: VUK'un 141. maddesine göre inceleme esnasında lüzum görülen hallerde düzenlenen tutanaklardan bir nüshanın mükellefe veya nezdinde inceleme yapılan kimseye bırakılması mecburidir. Bu hak mükellefin herhangi bir itiraz ve ihtilaf durumunda elini güçlendirecektir.

Tutanakları İhtirazi Kayıtla İmzalama Hakkı: VUK'un 141. maddesinde inceleme tutanaklarını düzenlemiştir. Maddeye göre, inceleme esnasında düzenlenen tutanaklara varsa ilgililerin itiraz ve mülahazaları kaydedilir.

Tutanağı İmzalama Hakkı: VUK'un 141. maddesinde, tutanakların imzalanamayabileceğini anlatılmaktadır. Tutanağı imzalamaktan çekinmenin yaptırımı da aynı maddede düzenlenmiştir. Buna göre, defterler mükellefe verilmeyecek ve vergi dairesinde saklanacaktır.

Doğru Vergi Miktarının Bulunmasını İsteme Hakkı: VUK'un 134. maddesinde incelemenin amacının ödenmesi gereken vergilerin doğruluğunu araştırmak tespit etmek ve sağlamak olduğu belirtildiğine göre, mükellefin doğru vergi miktarının bulunmasını isteme hakkı vardır. Bu bağlamda, inceleme elemanının sadece devlet lehine değil varsa mükellef lehine de tespitler yapma zorunluluğu vardır.

Vergi Mahremiyetine Uyulmasını İsteme Hakkı: VUK'un maddesinde vergi mahremiyetine uymak zorunda olan kimseler belirtilmiştir. Bu kimseler arasında belki de bu yasağa uyması en önemli olan vergi incelemesi yapanlar da vardır. Vergi incelemeleriyle uğraşan kimseler mükelleflerin defter ve belgelerine belki de en çok hâkim olan kimseler olduklarından bu kimselerin vergi mahremiyetine uyması mükellef için ticari hayatı açısından hayati önem taşır. 
Mükelleflerin hakları VUK dışında bazı kanun ve yönetmeliklerle de güvence altına alınmıştır. Bunlar aşağıda maddeler halinde sıralanmıştır:

Defter ve Belgeleri Zimmetle Teslim Etme Hakkı: Vergi İncelemelerinde Uyulacak Usul ve Esaslar Hakkında Yönetmelik'in 12. maddesine göre mükelleflerin defter ve belgelerinin tutanakla teslim alınması gerekir. Bu husus mükellefin diğer kanunlarda yer alan sorumluluklarının bir sonucudur. Örneğin defterlerini muhafaza ve gerektiğinde ibraz etmeyen mükellefe; 506 Sayılı SSK'nın 140. maddesine göre idari para cezası verilir, 1994 tarih ve 4054 sayılı Rekabetin Korunması Hakkında Kanunun 17/1-d bendine göre süreli para cezası verilir. Eğer mükellef tacir ise defter ibraz etmemenin yaptırımı ağırdır. Çünkü mahkemeye defterini ibraz etmeyen tacir, TTK'nın 85. maddesine göre aynı kanunun 86. maddesine göre karşı tarafın defterlerinin aleyhine delil olması tehlikesi ile karşı karşıya kalır. Defter ve belgeler mükellef için bu kadar önemli iken tutanakla alınması gerekli bir zorunludur. Çünkü mükellef defter ve belgelerine diğer kurumların isteği nedeniyle ihtiyaç duyması elinde defter belgelerinin inceleme elemanlarında olduğuna dair bir belge olması gerekir.

Eşit ve Rekabeti Koruyucu Şekilde İşlem Görme Hakkı ve Bu Bağlamda Toplu İnceleme Yapılmasını İsteme Hakkı: 5345 sayılı Gelir İdaresi Başkanlığının Teşkilat ve Görevleri Hakkında Kanun'un 1. maddesi "gelir politikasını adalet ve tarafsızlık içinde uygulamak" hususunu kanunun amaçları arasında ve birinci sırada saymıştır. Yine Anayasanın 10. maddesi herkesin dil, ırk vb. ayrım gözetmeksizin kanun önünde eşit olduğunu belirttikten sonra, son fikrada devlet organları ve idari makamların bütün işlerinde bu ilkeye uymak zorunda olduklarını bildirmiştir. İdare bütün işlemlerinde olduğu gibi vergi incelemesinde de eşit işlem ilkesini gözetmek zorundadır. Aksi halde bu durum ticari hayatta rekabet eşitliğini bozar.

İnceleme İsteme Hakkı: Mükelleflerin VUK'un 116-126 maddeleri kapsamında çözülmeyen vergi ve matrah hataları nedeniyle inceleme isteme hakları vardır. Ayrıca vergi iadeleri durumunda da mükelleflerin inceleme isteme hakları vardır. Vergi idaresinin bu talepleri VUK'un 134. maddesi gereği yerine getirmesi gerekmektedir.

İncelemeyi Vekil veya Temsilci Eliyle Yürütme Hakkı: Vergi ile ilgili kanunlarda mükellef veya vekil ya da temsilcisi gibi ifadeler kullanılır. Buradan mükellefin vergi incelemesini vekili veya temsilcisi eliyle yürütebileceği anlaşılmaktadır.

Susma ve Aleyhine Delil Göstermeye Zorlanmama Hakkı: Anayasanın 38/5 maddesinde temel haklar arasında düzenlenen "susma hakkı" vergi incelemesi sırasında da mevcuttur. $\mathrm{Bu}$ vergi incelemesinin mali ve bazı durumlarda adli soruşturma olma niteliğinin bir sonucudur. 


\subsection{Vergi İnceleme Sürecinde Mükellefin Yükümlülükleri (İdarenin Hakları)}

Türk Vergi Sisteminde inceleme sürecinde mükellefe düşen yükümlülükler aynı zamanda idarenin haklarını teşkil etmektedir. Mükelleflerin, bir kısmı vergi kanunlarında bir kısmı da diğer kanunlarda yer alan yükümlülükleri aşağıdaki gibidir:

- Vergi matrahını doğru beyan etmek ve ödenmesi gereken vergileri vadesinde ödemek;

- 6183 Say1lı AATUHK'un 9. ve 11. maddelerine göre; mükellefler vergi alacağının güvence altına alınabilmesi için istenilen teminatları sağlamak, teminatı sağlayamamaları durumunda ise kefil göstermek;

- VUK'un 257. maddesine göre müessesenin durumuna göre; vergi incelemesi yapana uygun bir çalışma yeri göstermek ve resmi çalışma saatleri içerisinde müessesede çalışmasına (düzenleme işlemleri resmi çalışma saatleri sonrasına sarkan bir tutanağın tamamlanmasına) izin vermek;

- VUK un 257. maddesine göre; vergi inceleme elemanına inceleme ile ilgili her türlü izahatı vermek ( $\mathrm{Bu}$ zorunluluk hem iş sahibini, hem de işletmede çalışanları kapsar);

- VUK'un 257. maddesine göre gerektiğinde, incelemeyi yapanın işyerinin her tarafını gezip görmesine izin vermek;

- VUK'un 257/5. maddesine göre incelemeye yetkili olanlar tarafindan işletmede VUK'un 134. maddesi gereğince envanter yapılması halinde araç, gereç ve personeliyle bu işlemlerin yapılması için gerekli yardım ve kolaylığı göstermek;

- VUK'un 148. maddesine göre; vergi incelemesine yetkili kişilerin talep edecekleri her türlü bilgiyi vermek (Mükellefler, VUK'un 151. maddesinde belirtilenler hariç olmak üzere, özel kanunlarda yazılı mahremiyet hükümlerini ileri sürerek, bilgi vermekten imtina edemezler);

- VUK'un 127/c maddesine göre; mükellef nezdinde yapılan yoklama sırasında kanuni defter ve belgeler dışında, vergi kaybının bulunduğuna emare teşkil eden defter, belge, kayıt ve benzeri delillerin tespit edilmesi halinde, mükellefler bunların yoklama yetkisine haiz elemanlarca alıkonulmasına karşı çıkmamak;

- VUK'un 141/2. maddesine göre; vergilendirme ile ilgili olay ve hesap durumlarını içeren tutanakları imzalamaktan çekindikleri hallerde, bunların dayanağı olan defter, belge ve kayıtların vergi inceleme elemanınca 
alıkonulması konusunda zorluk çıkarmamak (Söz konusu defter ve belgeler, inceleme sonucunda ortaya çıkan vergiler ve kesilen cezalar kesinleşinceye kadar geri verilmez. İlgililer, bu defterlerin suç delili olmaması şartıyla, her zaman bu tutanakları imzalayarak defter ve vesikaları geri alabilirler.);

- VUK'un 144. maddesine göre; yoklama veya arama sonucunda defter ve belgeler vergi inceleme elemanınca alıkonulup muhafaza altına alınmış olsa dahi, süresi gelen vergi beyannamelerinin verilmesi ödevini yerine getirmek (Mükellef beyannamesini tanzim için gerekli bilgileri defter ve vesikalardan inceleme yapanın huzurunda çıkarabilir);

- VUK'un 172. maddesine göre; tutmak zorunda oldukları defterlerden, aynı Kanuna göre tasdike tabi tutulanlarını zamanında tasdik ettirmek, tuttukları defterleri ve bunların dayanağını oluşturan belgeleri usulüne uygun bir şekilde tutmak ve ilgili bulundukları yılı takip eden takvim yılından başlayarak beş yıl süre ile muhafaza etmek;

- VUK'un 232., 234. ve 235. maddeleri uyarınca almak zorunda oldukları fatura, gider pusulası ve müstahsil makbuzlarını tarih sırası ile tanzim tarihlerini takip eden takvim yılından başlayarak beş yıl süre ile muhafaza etmek (VUK'un 254. maddesine göre defter tutmak zorunda olmayanlar);

- VUK'un 256. maddesine göre; muhafaza etmek zorunda oldukları her türlü defter, belge ve karneler ile vermek zorunda bulundukları bilgilere ilişkin mikro fiş, mikro film, manyetik teyp, disket ve benzeri ortamlardaki kayıtlarını ve bu kayıtlara erişim veya kayıtları okunabilir hale getirmek için gerekli tüm bilgi ve şifreleri, muhafaza süresi içerisinde yetkili makam ve memurların talebi üzerine ibraz ve inceleme için arz etmek. Vergi kanunlarına göre tutulan veya düzenlenen ve saklanma ve ibraz mecburiyeti bulunan defter, kayit ve belgeleri yok edenler, tahrif edenler veya gizleyenler-varlığı noter tasdik kayıtları veya sair suretlerle sabit olduğu halde, inceleme sirasında vergi incelemesine yetkili olanlara defter ve belgelerin ibraz edilmemesi gizleme demektir- hakkında VUK'un 359. maddesinde yer alan cezalar uygulanır.

\section{4. Çeşitli Ülkelerde Vergi Denetim Sistemleri}

Ülkeler bazında vergi denetim sistemleri incelenirken dikkat edilmesi gereken en önemli husus, ele alınan hiç bir ülke uygulamasında tek tip ve her biri birbiriyle aynı hiyerarşi ve uzmanlaşma düzeyinde ele alınmış tek bir denetim örgütlenmesinin mevcut olmadığıdır. 
4.1. Avrupa Birliğí2: AB üye ülkelerdeki vergi kayıp ve kaçaklarının birliğin mali menfaatlerine de zarar vereceği gerçeğinden hareketle bazı özel vergi denetim mekanizmaları oluşturmuştur. Avrupa Konseyi'nin 2185/96 sayılı ve 11 Kasım 1996 tarihli kararı uyarınca AB'nin mali menfaatlerine zarar veren düzensizlik ve kaçakların tespiti amacıyla, Komisyon tarafından işyerlerinde gerçekleştirilecek denetimleri ve diğer kontroller Komisyon'un sorumluluğu altında ve Komisyon'ca görevlendirilecek yetkin memurlar tarafından yapılacaktır. Ulusal ceza usul kanunlarına aykırı olmamak üzere, Komisyon'un kontrol görevlileri yapacakları denetim çalışmaları için ihtiyaç duyacakları tüm bilgilere, o ülkenin denetim elemanları ile aynı koşullar altında erişme hakkına sahip olacaktır. Komisyon denetimler sonucu tespit edeceği düzensizlikleri en uygun sürede ilgili devlete bildirecek ve komisyon'un görevlendirdiği denetim elemanlarınca düzenlenecek raporlar, üye devletlerin adli veya idari mekanizmaları karşısında "kabul edilebilir delil" olarak kabul edilecektir.

Ancak AB Konseyi'nin 25 Mayis 1999 tarih ve CE 1073/1999 ve 1074/1999 numaralı kararlarıyla daha önce sözünü ettiğimiz 2185/96 sayılı ve 11 Kasım 1996 tarihli kararlarda belirtilen ve Komisyon'ca görevlendirilecek denetim elemanlarının üye ülkelerde gerçekleştireceği denetimlerle ilgili görevlerin, bundan böyle OLAF (Avrupa Kaçakçılıkla Mücadele Ofisi)'a tevdi edilmesi kararlaştırılmıştır. Ayrıca OLAF'ın bağımsız ve tarafsızlığı açısından başkanına, uygun gördüğünde bir üye ülkede vergi incelemesi başlatma kararını alma insiyatifi tanınmıştır. OLAF'ın kendisi de dışarıdan, bağımsız çalışmak üzere seçilen kişilerden oluşacak özel bir Gözetim Komitesi tarafından düzenli olarak kontrol edilecektir. Komite, kendi ülkelerinde üst düzey kamu görevlisi sıfatıyla önemli ve özellikli kaçakçılık ve yolsuzluk incelemeleriyle (OLAF'ın çalışma alanıyla) ilgili görevlerde bulunmuş 5 üyeden oluşacaktır. AB'nin bu uygulaması üye ülkelerdeki denetim birimlerinin yetersiz kaldığı durumlarda bir takviye görevi üstlenmektedir. Ancak OLAF'ın sık sık bu görevini ifa etmesi birliğe üye ülkelerde hoş karşılanmayacağından, üye ülkelerin sistem yapısının uyarlaştırılması tarafımızca daha doğru olacaktır.

4.2. Almanya ${ }^{3}$ : Anayasa, Almanya'nın federal özelliğine uygun olarak, Federal devletin ve eyaletlerin kendi alanlarına giren vergilerin tespiti ve toplanması için ayrı örgütler kurmalarını zorunlu tutmuştur. Bunun yanısıra belediyeler de, kendilerine gelir getiren vergilerin toplanması için vergi dairelerini kurmuşlardır. Federal ve eyalet maliye örgütleri üç kademeden oluşmaktadır. Maliye Bakanlıkları en üst mali mercilerdir. Orta kademe mali merciler Yüksek Maliye Müdürlükleri (Oberfinanzdirektion) ve yerel mali

2 Bu başlı “Vergi Dünyası Dergisi”nin Ağustos 2011 Tarih ve 360 sayılı makalesinden yararlanılarak hazırlanmıştır.

3 Bu başlık Ayşe ŞAAN’ın "Türkiye'de Vergi Kaçakçılı̆̆ının Önlenmesin de Vergi Denetiminin Etkinliği”" Başlıklı Yüksek Lisans Tezinden yararlanılarak hazırlanmıştır. 
merciler de vergi daireleridir (Finanzamt). Almanya'da "teftiş" nitelikli denetim Sayıştay tarafindan ve vergi incelemesi de vergi dairesinde bulunan inceleme elemanlarınca gerçekleştirilmektedir. Almanya'da vergi incelemeleri beyana dayalı vergilerde yürütülmektedir. Vergi denetimi Almanya'da Yüksek Maliye Dairesine bağlı az sayıda ve Vergi Dairesi kadrolarında bulunan çok sayıda denetim elemanlarınca yürütülmektedir. Asıl vergi incelemeleri Vergi Dairesi kadrolarında yer alan inceleme elemanları tarafindan yapılmaktadır. Almanya'da vergi denetim elemanlarının Yüksek Maliye İdaresi ve Vergi Dairesi şeklinde sınıflandırılması Türkiye'de Vergi Denetim Kurulu öncesi düzenlemeyle tamamen farklı amaç taşımaktadır. Almanya'daki bu uygulama Almanya'nın fedaral bir yönetim sistemine sahip olmasının sonucudur.

4.3. İngiltere: İngiltere'de vergi idaresi 2005 yılına kadar iki ayrı birimden oluşmaktaydı. Bunlar: Gelir İdaresi (Inland Revenue) ile Gümrük ve Tüketim Vergileri İdaresi (HM Customs and Excise)'dir. 18 Nisan 2005 tarihinde Gelir İdaresi (Inland Revenue) ile Gümrük ve Tüketim Vergileri İdaresi'nin (HM Customs and Excise) birleştirilmesi ile İngiltere Gelir ve Gümrük İdaresi (HM Revenue and Customs) oluşturulmuştur.

4.4. ABD: ABD, federal bir yapıya sahiptir. Devletin gücü, Birleşik Devletler (Federal Devlet) ile 50 eyalet arasında paylaşılmaktadır. Gerek federal, gerekse eyalet düzeyinde devletin gücü bağımsız yasama, yürütme ve yargı kollarına ayrılmaktadır. ABD'de vergi denetimi gelir ajanları ve vergi denetim elemanları tarafindan yapılmaktadır. Vergi denetim elemanları yerel bazda inceleme yaparken gelir ajanları beyannameleri incelerler. Buradaki ayrımda yine federal sistemin getirdiği bir durumdur.

Yukarıda ülke örneklerinde de görüleceği üzere gelişmiş ülkelerde vergi denetim sisteminde çok başlılık yoktur. Vergi denetim birimlerinin yer yer bazı ülkelerde farklılaştırılması ise federatif devlet yapısının bir sonucudur. Bu nedenle Vergi Denetim Kurulu'nun kurularak çok başlılığın ülkemizde bertaraf edilmesi ülkemizin geleceği açısından önemli bir adımdır.

\section{Vergi Denetiminin Önemi}

Vergi devletin kamu harcamalarını karşılayabileceği en önemli gelir kaynă̆ıdır. Verginin karşılıksız olması, toplumda en fazla vergi ödeyenlerin en az kamu hizmetinden yararlanması gibi düşünceler nedeniyle toplumda dirençle karşılaşması normaldir. Devlet vergiye gönüllü uyumu sağlamak için vergilemede eşitlik, genellik gibi ilkelere ihtiyaç duyar. Anayasamızın 73. maddesinin birinci fikrasında "Herkes kamu giderlerini karşllamak üzere mali gücüne göre vergi vermekle yükümlüdür”. Söz konusu fikra vergi adaletini sağlamak üzere getirilmiş düzenlemelerin yasalara yansımasının en güzel örneğidir. Ancak tüm düzenlemelere rağmen vergiye gönüllü uyumu yüzde yüz temin 
etmek mümkün değildir. Ülkemizde vergilemede beyan esasının geçerli olması vergi tahsilâtı açısından gönüllü uyumu yetersiz kılmakta ve devletin caydırıcı uygulamalara gitmesi gerekmektedir. İşte vergi denetimi bu caydırıcı uygulamalar içerisinde en önemli yere sahiptir. Beyana dayalı sistemlerde etkin olmayan bir vergi denetimi kayıt dışı ekonominin kayıt altına alınmasını zorlaştıracak ve vergi matrahında aşınmalar meydana gelecektir.

Her geçen gün daha da karmaşı hale gelen iktisadi yaşam beyan edilen vergilerinin doğruluğunun tespitini zorlaştırmakta ve vergi denetimine duyulan ihtiyaç gün geçtikçe artmaktadır. Diğer yandan vergi mevzuatının geniş oluşu, kolay anlaşılamaması, teşvik, muafiyet ve istisnaların çokluğu, kişilerin gelecek planlarını doğru yapamayacakları kadar sıklıkta değişikliklere gidilmesi, af kanunları ve beyan esasına dayanan vergi sistemleri ekonomik birimlerin vergi kaçırma eğilimini artırmaktadır. Ayrıca vergi dairelerinin görevlerini yerine getirirken etkin çalışamıyor olması ve mükelleflere davranışları toplumun vergiye gönüllü uyumunu olumsuz etkilemektedir. Vergi denetimi mükellefleri doğru vergi vermeye yönelterek mükellefleri vergi kanunlarını öğrenmeye yöneltmekte böylece vergi bilincinin oluşmasına da yardımcı olmaktadır. İşletmesinin vergi incelemesi geçireceği düşüncesi mükellefleri araştırmaya, uzman kişilere danışmaya ve muhasebeyle yakından ilgilenmeye zorlamaktadır. Böylece mükellefler farkında olmadan piyasadaki diğer şirketlerin karlılık oranlarını, gider kalemlerini, hukuki yapılarını öğrenerek iktisadi faaliyetlerini daha etkin yürütmekte, bu yönüyle vergi denetimi özel piyasanın gelişmesine de fayda sağlamaktadır. Mükellefler vergi incelemeleri sonucu aleyhlerine tarh edilecek vergi ve cezalardan kurtulabilmek için alanında uzman yeminli mali müşavirler ve danışmanlarla çalışmakta hatta işletmeleri bünyesinde iç denetim mekanizmaları oluşturmaktadırlar. Bu sayede mükellefler işletme içinde yer alan vergi dışı kayıp ve kaçakların da farkına vararak gerekli önlemleri alabilme şansı yakalayabilmektedirler.

Vergi denetimlerinin ilk aşamadaki sonucu, vergi, ceza, gecikme zam ve faizleriyle devlete önemli oranda finansman olanağı yaratmasıdır. Mevcut vergi potansiyelinden tam olarak faydalanılması, vergi dışı bırakılmış kaynakların ortaya çıkarılması devleti mali açıdan önemli ölçüde rahatlatma özelliği taşımaktadır (İyibil, Arıca, 1985: 4). Denetimler bir yandan fiilen mevcut olan diğer yandan potansiyel vergi kayıp ve kaçağını önlemek fonksiyonuna sahip olduklarından, denetimin ilk ve en önemli amacı devlete ek gelirler sağlamaktır. Aşağıdaki tabloda 2011-2012 yılları vergi inceleme sonuçları gösterilmiştir. 2012 yılı genel bütçe gelirlerinin tutarının 362.654.794.000,00-TL olduğu göz önüne alındığında vergi denetiminin ülke ekonomisi açısından önemi daha anlaşılır olmaktadır. 
Tablo: 2

Yıllar İtibarıyla Vergi İnceleme Sonuçları

\begin{tabular}{|c|c|c|c|}
\hline Yıllar & İncelenen Mükellef Sayısı & Tarhı Önerilen Vergi Tutarı & Kesilmesi Önerilen Ceza \\
\hline 2011 & 16.267 & $3.926 .153 .961,00$ & $6.540 .331 .412,00$ \\
\hline 2012 & 46.845 & $4.535 .523 .091,00$ & $8.776 .095 .415,00$ \\
\hline Toplam & $\mathbf{6 3 . 1 1 2}$ & $\mathbf{8 . 4 6 1 . 6 7 7 . 0 5 2 , 0 0}$ & $\mathbf{1 5 . 3 1 6 . 4 2 6 . 8 2 7 , 0 0}$ \\
\hline
\end{tabular}

Kaynak: Vergi Denetim Kurulu Başkanlığl, 2013 Yılı Genel Çalışma Planından yararlanılarak hazırlanmıştır.

Ayrıca denetimler sonucu elde edilen ek gelir miktarı denetlenen mükelleflerle sınırlı kalmamakta vergi sistemi içerisinde hedeflenen belge düzeni sayesinde denetime tabi tutulmamış mükelleflerin beyanlarını da olumlu yönde etkilemektedir (Meriç, 2002: 22). Örneğin vergi denetimleri sonucu belgesiz mal alışı yapan mükelleflere cezai işlem uygulanması, mükellefleri belgeli mal almaya itmekte ve böylece mükelleflere fatura alıp verme bilinci yerleştirilmektedir.

Vergi kayıp ve kaçağı nedeniyle kamu gelirlerinin giderleri karşılayamaması sonucu borçlanmaya başvurulması, vergi oranının artırılması veya sisteme yeni vergiler dahil edilmesi, ülke ekonomisini etkilemektedir. Bu bakımdan, ekonomik dengenin sağlanması ve istenilen etkilerin gerçekleştirilebilmesi için vergilerin amacina uygun bir şekilde alınması ve kullanılması gerekir. Bu durum, vergi kaybı ve kaçağı sorunu üzerinde durmayı, dolayısıyla vergi denetimine önem vermeyi zorunlu kılar (İyibil, Arıca, 1985: 45). Bu yönüyle vergi denetimi devletin uygulamak istediği maliye politikalarının başarıya ulaşmasına katkı sağlar.

VUK'un 134. maddesinde vergi incelemesinden maksat, ödenmesi gereken vergilerin doğruluğunu araştırmak, tespit etmek ve sağlamaktır. Kanun maddesinde vergi denetiminin araştırma fonksiyonundan bahsedilmiştir. Araştırma fonksiyonu vergi denetiminin en önemli fonksiyonları arasındadır. Eğer vergi yönetimi, vergi denetimi aracılığıyla yükümlülerin beyanlarını gereği gibi kontrol edemiyorsa; vergi yasalarına hata ile veya kasten aykırı hareketleri araştırarak ortaya çıkaramıyorsa vergi denetiminin sonuçları olan müeyyideler işletilemeyecek demektir (Şeker, 1994: 38). Bu yönüyle vergi denetimi mükelleflerinin defter ve belgelerinde yer alan hata ve hileleri tespit ederek tahsil edilmesi gereken vergiyi araştırır.

Ayrıca vergi denetimleri, vergi toplamanın yanında Devletin egemenliğini de gösteren önemli bir göstergedir. Öyle ki TBMM'de kabul edilen ilk kanun şu an yürürlükte olmayan "Ağnam Resmi” ile ilgili bir kanun olmuştur. Devletin yasalarla koyduğu vergileri toplamaktaki başarısı, egemenliğinin ve gücünün sembolü haline gelmiştir. Aksi halde vatandaşlar devletin koyduğu kurallara saygı duymakta zorlanırlar. 


\section{Vergi Denetim Sisteminde Yer Alan Aksaklıklar}

Günümüzde vergi denetim sistemi mükelleflerin kendi tespitlerine dayanarak beyan ettikleri vergilerin, vergi denetim birimlerince kontrol edilmesi sistemine dayanır. Vergi denetimi beyana dayalı sistemlerin olmazsa olmaz tamamlayıcı unsurudur. Vergi denetim sisteminin etkin bir şekilde işlememesi devletin uygulayacağı maliye ve ekonomi politikalarının başarı oranını önemli bir şekilde düşürür. Devletin toplum içerisindeki hükümranlık gücünün inanılırlığı açısından da vergi denetimi büyük öneme sahiptir. $\mathrm{Bu}$ yüzden vergi denetim sisteminde yer alan aksaklıkları iyi tespit etmek gerekir. Vergi denetiminde istenilen sonuca ulaşlabilmesi, sadece vergi denetim sisteminde birtakım düzenlemelere gidilmesiyle mümkün olmayacak olaya bir sistem sorunu olarak bakılması halinde sorunlar birbirini tamamlar şekilde çözülebilecektir.

Ülkemizde vergi denetimi, kamunun diğer tüm birimlerinde olduğu gibi hatalar yapıldıktan, olaylar sonuçlandıktan sonra yapılan tespit ve önerilen cezalar haline dönüşmesi, vergi denetimini sadece hata raporu şekline dönüştürmektedir. Oysa vergi denetimi durum analizini de kapsamalıdır. Vergi denetim birimlerinde ki iş yoğunluğunun da etkisiyle sadece hata yapan mükellefler incelemeye tabi olmakta vergi denetim birimleri ellerindeki işleri bitirmeyi amaç haline getirmekte ve böylece riskli ya da sıkıntılı sektörlere önlem amacıyla denetimler çok az yapılabilmektedir. Denetimler genelde ihbarlar sonucu yahut vergi kaçırdığına dair herhangi bir veri elde edilen mükellefler üzerinde yoğunlaşmaktadır. Bu durum da vatandaşları doğru vergi beyanına değil, yakalanmamak için tedbirler almaya itmektedir. İncelemeye takılan mükelleflerin tek suçu yakalanmakmış gibi bir algı ortaya çıkmaktadır.

Vergi incelemesi kapsamında bulunan mükelleflerden hangilerinin öncelikle inceleneceğine dair VUK'da bir düzenlemenin yer almaması da bir başka sorundur. İncelemeler genelde ihbar ya da risk analiz sistemlerinin uyarısı sonucu yapıldığından öncelik sıralaması da yapılamamakta bu durum vergi incelemelerinin verimini düşürmektedir.

Vergi denetiminin, kayıtların denetimi haline gelmesi vergi sistemimizde önemli bir sorun oluşturmaktadır. Kayıtların denetimi sadece kayıt altında olan mükelleflerin denetimine ve sonuçta hem vergi yüklerinin ve hem de denetim yüklerinin kayıtlı mükelleflerin üzerinde yoğunlaşmasına sebep olmuştur (Karyağdı, 2001: 133). Bu nedenle faaliyetlerini yasal defter ve belgelere kaydeden mükellefler adeta cezalandırılır hale gelmiş ve mükellefleri kayıt dışılığa yönelten bir denetim mekanizması ortaya çıkmıştır.

Vergi denetim sisteminde yer alan en büyük sorunlardan biri de örgütsel sorunlardır. 646 Sayılı Kanun Hükmünde Kararname ile yapılan düzenlemeyle daha önce Hesap Uzmanları Kurulu, Gelirler Kontrolörleri, Maliye Teftiş Kurulu ve Vergi Denetmenleri olarak yer alan dört farklı denetim birimi tek çatı altında Vergi Denetim 
Kurulu olarak toplanmıştır. 646 Sayılı Kanun Hükmünde Kararname ile yapılan düzenlemeyle, Vergi Denetim Kurulu'na verilen görevlerin yerine getirilmesinde, uygun görülen yerlerde Bakan onayı ile doğrudan Vergi Denetim Kurulu Başkanlı̆̆ı'na bağlı olmak üzere;
a) Küçük ve Orta Ölçekli Mükellefler Grup Başkanlığı,
b) Büyük Ölçekli Mükellefler Grup Başkanlığg,
c) Organize Vergi Kaçakçılı̆̆ı ile Mücadele Grup Başkanlığı,
ç) Örtülü Sermaye, Transfer Fiyatlandırması ve Yurtdışı Kazançlar Grup Başkanlığ 1

şeklinde dört grup başkanlığı kurulması öngörülmüş̧ür. Ancak bu düzenleme isim ve unvan değişikliğinden öte gidememiş aynı ünvanla bakana bağlı olarak çalışan vergi müfettişleri, aynı vergi kanunlarını uygularken ölçek sınırlamasına tabi tutulmuşlardır. $\mathrm{Bu}$ düzenlemeyle Küçük ve Orta Ölçekli Mükellefler Grup Başkanlığı'nda hangi inceleme elemanlarının, diğer grup başkanlıklarında hangi inceleme elemanlarının görev yapacakları ayrıntılı olarak belirlenmiştir. Bu durumda, her bir mükellefin, hangi grupta yer alan inceleme elemanlarınca inceleneceğini, o mükellefin ölçek büyüklüğü belirleyecektir. $\mathrm{Bu}$ uygulamayla aynı kanunları uygulayacak vergi müfettişleri mükellefin ölçek büyüklüğü nedeniyle farklı gruplar altında toplanmışlardır.

Küçük ve Orta Ölçekli Mükellefler Grup Başkanlığı dışında çalışan vergi müfettişlerinin büyük ölçekli mükellefleri inceleyecekleri gerekçesiyle, büyük ölçekli mükellefler mükerrer vergi incelemesine tabi tutulmakta ve ülke ekonomisinde önemli yeri olan büyük mükellefler adeta devlete küstürülmektedir. Bu durumda mükellefler tek suçları büyük ölçekli olmak gibi bir düşünceye kapılmaktadırlar.

Küçük ve Orta Ölçekli Mükellefler Grup Başkanlığı dışındaki vergi müfettişlerinin görev yerleri İstanbul, İzmir ve Ankara şehirleri olduğundan diğer illerde yer alan büyük ölçekli mükellefler yerinde denetlenememekte turne kapsamında yukarıda değindiğimiz b, c, ç gruplarında yer alan vergi müfettişlerince denetlenmektedir. Örneğin Adana ilinde Maliye Bakanına bağlı aynı unvanla çalışan vergi müfettişi bulunurken, Ankara'dan denetim elemanı görevlendirilmekte ve bu durum kıt olan kamu kaynaklarının müfettişe sağlanacak yolluk, harcırah gibi ekstra masraflar nedeniyle israfina yol açmaktadır. Ayrıca Küçük ve Orta Ölçekli Mükellefler Grup Başkanlığı'nda çalışan vergi müfettişlerine, rotasyon uygulanırken diğer üç Grup Başkanlıklarında yer alan vergi müfettişlerine uygulanmaması devletin merkezde yer alan vergi müfettişlerinin yerelleşmeyeceğini, onlara daha fazla güvendiğini, buna karşıllk Küçük ve Orta Ölçekli Mükellefler Grup Başkanlığı'nda görev yapan vergi müfettişlerinin ise yerelleşebileceğini düşündüğü gibi bir algı yaratmakta ve uygulamadaki adaletsizlik Küçük ve Orta Ölçekli 
Mükellefler Grup Başkanlığı'nda görev yapan vergi müfettişlerinin motivasyonunu bozmaktadir.

Vergi mevzuatımızda çeşitli belirsizliklerin ve boşlukların olması, vergi kanunlarının çok sık değişmesi, sistemin çok karışık olması dolayısıyla farklı yorumlara yol açması, ülkenin ekonomik ve sosyal şartlarına uygun olmaması da vergi denetiminden istenilen sonucun alınmasına engel olmaktadır (Akbay, 1990: 230). Öyle ki vergi denetimi konusunda uzman olan kişiler dahi mevzuatı araştırmadan sorulara cevap veremez olmuştur. Örneğin Katma Değer Vergisi Kanunu yürütme maddeleri dâhil 63 maddeden oluşurken, uygulamaya ilişkin tebliğ sayısı 124 adettir. Bu durum denetim elemanlarının ve mükelleflerin işini çok zorlaştırmaktadır. Mevzuatta sıklıkla değişiklik yapılması geçiş hükümleri konusunu gündeme getirmekte bu durum da çok büyük karışıklıklara neden olmaktadır. Örneğin; yatırım indirimi uygulamasında defalarca değişikliğe gidilmiş hatta bazı maddeler Anayasa Mahkemesi kararıyla uygulanamaz hale gelmiş ve mükellefler bu indirim hakkından yararlanamaz veyahut yanlış yararlanır hale gelmiştir.

3568 sayılı Kanunla, meslekte 10 yılını tamamlayan denetim elemanlarına Yeminli Mali Müşavir olabilme imkânı tanınması, ayrıca özel sektörde de kamuda vergi denetiminde çalışan personelin rahatlıkla iş bulabilmesi, özlük hakları yapılan işin önemi ve riskiyle orantısız olan vergi müfettişlerinin özel sektöre geçişlerine neden olmakta ve müfettiş sayısında aşınmalar meydana getirerek vergi denetimi personelinin yetersizliği sorununu doğurmaktadır. Son yıllarda devlet vergi müfettişi alımını artırmıştır, ancak bir vergi müfettişinin yetişmesi uzun yıllar aldığından sıkıntılar hala devam etmektedir. Devlet yetiştirdiği elemanın özel sektöre geçişini engellemek ve daha fazla verim alabilmek için denetim elemanlarının özlük haklarını iyileştirmelidir. Aşağıdaki Tabloda 01.01.2013 tarihi itibariyle Maliye Bakanlığı'nda görevli vergi müfettişlerinin kadro dağılımı yer almaktadır. Tablodan da görüleceği üzere vergi müfettişi kadrosundaki doluluk oranı \%33 gibi düşük bir rakamdır.

Tablo: 3

\section{Vergi Denetim Kurulu'nun Kadro Durumu}

\begin{tabular}{|l|c|c|c|}
\hline Unvanı & Toplam & Dolu & Boş \\
\hline Vergi Başmüfettişi & 989 & 367 & 622 \\
\hline Vergi Müfettişi & 6094 & 2.497 & 3597 \\
\hline Vergi Müfettiş Yardımcısı & 7155 & 1.894 & 5261 \\
\hline Toplam & $\mathbf{1 4 . 2 4 3}$ & $\mathbf{4 . 7 6 3}$ & $\mathbf{9 . 4 8 0}$ \\
\hline
\end{tabular}

Kaynak: Vergi Denetim Kurulu Başkanlığı, 2013 Yılı Genel Çalışma Planından yararlanılarak hazırlanmıştır.

Bilgilerin düzenli bir şekilde saklanabilmesi ve işlem hızının artması açısından devletin gelişen teknolojiden en iyi şekilde faydalanması gerekmektedir. Elektronik sistemlerin denetim sürecinde kullanılması vergi denetiminin etkinliğini artıracaktır. Ancak günümüzde vergi dairelerinin arşivleri yeni yeni elektronik kayıt altına alındığından 
vergi denetim elemanları mükellef bilgilerine sadece tarh dosyalarından ulaşabilmektedir. Tarh dosyalarının vergi dairesinden vergi denetim elemanlarına taşınması ise zaman açısından maliyetli, güvenlik açısından risklidir. Ayrıca noterler, bankalar, tapu sicil müdürlükleri, belediyeler, trafik gibi kuruluşlarla vergi idaresi arasında bilgi alışverişini hızlandıracak teknolojik altyapının oluşmamış olması vergi idaresinin ve denetiminin verimliliğini azaltmaktadır.

Diğer bir husus ise ülkemizde kayıt dışı ekonominin yüksek oluşunun belge düzeni sorununu da beraberinde getirmesidir. Kayıtlı işlemlerin incelemeye daha çok konu olması elektronik defter ve belge düzenine tam olarak geçilememesi ve mükelleflerin düzenlemesi gereken belgelerin çokluğu mükellefleri belge düzenlememeye götüren nedenlerdir. Ayrıca farklı mükelleflerin farklı belge düzenlemesi gerektiği hususu da uygulamada sikıntılar yaratabilmektedir. Örneğin; defter tutan mükelleflerin defter tutmayan çiftçilerden mal ve hizmet alması halinde müstahsil makbuzu, defter tutmayan çiftçiler dışındaki esnaftan mal ve hizmet alması halinde ise gider pusulası düzenlemesi gerekmektedir. $\mathrm{Bu}$ gibi nedenlerle belge düzeninin yerleşememesi ve sağlıklı belge takibinin yapılamaması vergi denetimini ve vergi idaresinin işlerini zorlaştırmaktadır.

Ayrıca, inceleme sonucu önerilen tarhiyatların büyük kısmının yarg1 mercilerince terkini, vergisel af doğuran yasaların düzenlenmesi ve uzlaşma müessesesinin varlığı vergi incelemelerinin işlevlerini ve caydırıcılık özelliğini azaltmıştır. İlk olarak 1963 y1lında Türk Vergi Sistemine giren uzlaşma müessesesinin kapsamı 1987 yılında genişletilmiştir. Günümüzde uzlaşma komisyonu yetkileri sınırsız olan bir kurum haline gelmiştir. Yasada her ne kadar, uzlaşma talep edilebilmesi için; kanun hükümlerine yeterince nüfuz edilememesi, yanılma halinin bulunması, vergi hatası veya her türlü maddi hata bulunması ve yargı kararları ile idarenin ihtilaf konusu olayda görüş farklılığının olması gerektiği belirtilse de uygulamada bu nedenlerle sınırlı kalınmamakta ve uzlaşma müessesesinin kapsamı genişletilmiş durumdadır.

Devlet vergi tahsilâtlarını artırmak ve cari dönemin bütçe açıklarını gidermek için bu tür uygulamalara gitmekte, ancak vergi denetiminin caydırıcılığını ve vergi yasalarının güvenilirliğini azaltarak günü geleceğe feda etmektedir.

\section{Sonuç ve Öneriler}

Geçmişi Eski Mezopotamya'ya kadar dayanan vergi denetiminin, en ilgi çekici bölümü olan vergi incelemesi devletin vergi yasalarına duyulan güvenin sağlanması ve bütçeye sağladığı önemli katkılar nedeniyle stratejik öneme sahip bir alan olmuştur. Ayrıca vergilendirme işlemlerinde, işlemlerin gerçek mahiyetinin ortaya konması görevinin vergi idaresine ait olması, idarenin kanunlarla koyulan vergi yasalarının uygulanabilirliğini güvence altına almasını sağlamaktadır. Vergi denetimi bu yönüyle hükümetlerin 
hükümranlık güçlerini de artırdığından denetim kurulları her zaman en etkin kurumlar olmuştur. Devletin vergi yasaları aracılığıyla ulaşmak istediği politikalardan beklenen sonucu alabilmesi beyan sisteminin doğru işlemesine bağlıdır. Bu sistemin de caydırıcı unsuru vergi denetim ve incelemeleridir.

Ülkemizde vergi incelemesi kapsamında bulunan mükelleflerin öncelik sıralamasının olmaması, vergi denetiminin etkinliğini bozan nedenlerdendir. Vergi incelemelerinin verimli sektörlere kaydırılması vergi inceleme birimlerinin iş yükünü azaltacak ve vergi hâsılatını artıracaktır. Bu sorunun çözümü açısından sektörel risk analizlerinin yapılması ve incelemelerin riskli sektörlere doğru yönelmesi gerekir. Nitekim Vergi Denetim Kurulu risk odaklı veri analizi stratejisini benimsemiş, bu yönlü çalışmalarını sürdürmektedir.

Ayrıca mükellef hakları ve idarenin haklarının gözetilmesi hususunda gerekli yasal düzenlemelerin ve kurumsal altyapıların oluşturulması, gerek mükelleflerin gerekse de inceleme elemanlarının motivasyonunun artmasını sağlayacaktır. Mükelleflerin devlete küstürülmemesi ne kadar önemli ise inceleme elemanını da görev motivasyonunun bozulmaması o kadar önemlidir. Ne kadar iyi yetişmiş olursa olsun gerekli yetkileri elinde bulundurmayan bir inceleme elemanının etkin denetim yapamayacağı gibi, ne kadar vatansever olursa olsun haklarının ihlal edildiğini düşünen bir mükellef de vergisel ödevlerini yerine getirmekten kaçınacaktır.

Ülkemizdeki vergi kanunlarının çok sık değişmesi nedeniyle vergi mevzuatının gittikçe karmaşık hale gelmesi bu konuda uzman kişi sıkıntısı çekilmesine neden olmakta ve bu durum vergi ile ilgili danışmanlık hizmetlerini getirisi yüksek bir piyasa haline getirmektedir. Yetki ve özlük sıkıntı çeken vergi inceleme elemanına piyasadan bu denli talep gelince yetişmiş eleman erozyonu başlamakta ve vergi inceleme elemanı sıkıntısı yaşanmaktadır. Devlette inceleme ile uğraşan ve mükelleflerin ne yaparsa incelemeye tabi olacağını, incelemenin hangi hususlarda yapıldığını iyi bilen inceleme elemanının özel sektöre geçişi, vergiden kaçınmaların artmasına neden olacaktır.

Vergi incelemelerinde eleştiriye konu diğer bir husus, incelemelerin kayitlı mükellefler üzerinde yoğunlaşmasıdır. Bütün işlemlerini kayıt altına alan mükelleflerin en küçük hataları bile banka sistemleri ve veri sistemleri nedeniyle incelemeye takılmaktadır. Buna karşın vergi kaçırma eğiliminde olan mükellefler kayıt dışı yöntemler benimseyerek faaliyetlerini sürdürmeye devam etmektedirler. Bu nedenle başta kayıt dışı ekonomik faaliyetlerin minimize edilmesi ve tüm mükelleflerin gerekli vergi bilincine kavuşturulmasını sağlayacak düzenlemelerin yapılması gerekmektedir.

Vergi idaresinin daha güçlü bir yapıya kavuşturulması, vergi işlemleriyle uğraşan birimlerin mükellef odaklı bir yapıya dönüştürülmesi, bu konuda Avrupa Ülkeleri’nde yer alan vergi sistemlerinin örnek alınmasının da vergi denetiminde yer alan 
sıkıntıları giderebilmek açısından faydalı olacaktır. $\mathrm{Bu}$ anlamda 646 Sayılı Kanun Hükmünde Kararname ile Vergi Denetim Kurulu'nun kurulması ve vergi dairelerinde otomasyona gidilmesi çalışmaları umut verici olsa da böylesine stratejik önemi olan bir alanda yetersiz kaldığ 1 bir gerçektir.

Beyana dayanan vergi sistemine sahip ülkemizde vergi denetimine en az harcama denetimi kadar önem verilmelidir. Çünkü beyana dayalı vergi sisteminin temel direği vergi denetimleridir. Vergi denetiminin hata raporu şekline dönüşmemesi için durum analizleri de yapılmalıdır. Bunu sağlamak için sektörel risk analizleri yapılmalı, riskli sektörler öncelikle incelenmelidir. Böylece mükellefler yakalanmamak için değil kanunlara uygun işlem yapmaya yönlendirilmiş olur. Risk analizleri yapılırken de istatistiki veriler ve kanun boşluklarıda göz önünde bulundurulmalıdır.

Öngörülen vergi denetim modeli, gelişmiş ülkelerdeki gibi; incelenecek mükelleflerin objektif ölçütlere göre belirlenmesini, başlanan incelemelerin tarafsız olarak yürütülüp sonuçlandırılmasını, incelemeler sırasında mükellef haklarının da göz önünde bulundurulmasını güvence altına almalıdır.

Vergi denetim sistemi içerisinde yer alan denetim elemanları üst düzey eğitim ve uygulama deneyimleriyle Türk vergi ve mali sistemi ile ekonomisine yararlı olacak şekilde yetiştirebilmelidir. Bu nedenle vergi denetim elemanlarına yurt dışı ve akademik kariyer imkânları sağlanmalıdır. Mevcut düzenlemeye göre vergi müfettiş ve yardımcılarının mesai saatleri içerisinde yüksek lisans yapmaları yasaklanmıştır. Oysa denetim işi ile uğraşan elemanların geniş bir vizyona sahip olmaları açısından akademik çalışmalar çok önemlidir.

VUK'un 134. maddesinde vergi incelemesinden maksadın ödenmesi gereken vergilerin doğruluğunu tespit etmek olduğu belirtilmiştir. Bu nedenle Vergi inceleme elemanları mali savcı gibi hareket ederek sadece hazine çıkarlarını değil aynı zamanda mükellef haklarını da gözetmelidir.

Vergi denetim birimlerinde yeni teknolojik imkânlardan faydalanacak şekilde tam otomasyona gidilmelidir. Ayrıca kamunun diğer birimleriyle yapılacak protokollerle vergi incelemesi yapan elemanlara bilgi erişimi sağlanmalıdır.

Aynı işi yapan ve aynı ünvanla çalışarak tek amiri bakan olan vergi müfettişleri arasında Vergi Denetim Kurulu öncesinden kalma alışkanlıklardan vazgeçilmeli, kast sistemine son verilerek mevcut denetim elemanları arasında bütünleşme sağlanmalıdır. Böylece vergi denetim elemanlarının iyi bir kurum kültürüne sahip olmalarına katkı sağlanmış olur. 
Yerelleşme sadece taşrada çalışan denetim elemanlarına özgü bir durum değildir. Bu nedenle rotasyon sadece taşra denetim birimleri için değil merkezi denetim birimleri için de uygulanmalı yahut her iki birim için de uygulanmamalıdır. Aksi halde devletin merkezdeki inceleme elemanlarına daha çok güvendiği gibi bir çifte standart durumu ortaya çıkmaktadır.

Vergi İnceleme elemanlarının özlük sıkıntıları giderilerek, bu meslekte tecrübe sahibi olmuş, yetişmiş elemanların özel sektöre geçişi önlenmelidir. Çünkü tecrübeli elemanlara idari kadrolarda da ihtiyaç vardır.

\section{Kaynakça}

Akbay, M. (1990), “Vergi İncelemeleri ve Vergi Denetimi”, 1990 Yılına Girerken Türkiye'de Denetim, Etkinlik ve Verimlilik Sempozyumu, Maliye ve Gümrük Bakanlığı, A.P.K.K. Yayın No: 1990/308, Ankara.

Binbirkaya İ. (2006), “Türkiye’de Vergi Denetimi ve Kayıt dışı Ekonomi”, Yayınlanmamış Yüksek Lisans Tezi, İstanbul Üniversitesi, Sosyal Bilimler Enstitüsü, İşletme Anabilim Dalı, İstanbul.

Candan, T. (2001), Vergilendirme Yöntemleri ve Uzlaşma, Yaklaşım Yayınları.

Gürboğa, E. (2004), “Kayıt Dışı Ekonomi ile Mücadelede Yoklamanın Önemi”, Vergi Sorunları, Ağustos, Say1: 191.

Güredin, E. (2007), Denetim ve Güvence Hizmetleri, 11. Bas1, Arıkan Matbaas1.

Hastürk, M. (2010), “Türkiye'de Vergi Denetiminin Etkinliğinin İncelenmesi ve Değerlendirilmesi”, Yayınlanmamış Yüksek Lisans Tezi, Gazi Üniversitesi, Sosyal Bilimler Enstitüsü, Ankara.

Hesap Uzmanları Kurulu, Denetim Illke ve Esasları, Mart/2013.

İyibil, A. \& M.N. Arıca (1985), İşletmelerde Vergi Denetimi, Maliye Bakanlığı Gelirler Baş Kontrolörleri Yayını.

Karyağdı, N. (2001), Toplam Kalite Yönetimi ve Türk Vergi İdaresi, A.S.O. Yayın No: 51, Ankara. Maliye H.U.D. (1995), “Türk Vergi Sistemi ve 50. Yılında Hesap Uzmanları Kurulu”, HUK 50. Yıl Armağanı, İstanbul.

Meriç, M. (2002), Vergi Denetimi, İlkem Ofset, İzmir.

Öncel, M. \& A. Kumrulu \& N. Çağan (2008), Vergi Hukuku, Turhan Kitabevi.

Şeker, N. (1994), Hukuksal Yapısıyla Vergi İncelemesi, Beta Basım Yayın Dağıtım, 1994.

Vergi Denetim Kurulu Başkanlığı, 2012 Yllı Faaliyet Raporu, $<$ http://www.vdk.gov.tr/File/?path=ROOT\%2FDocuments\%2FDosya\%2Fvergi+denetim +kurulu_200513.pdf $>$, 23.12.2013.

Vergi Denetim Kurulu Başkanlığı, 2013 Yılı Genel Çalışma Planı, <www.vdbis.gov.tr>, 27.12.2013. 
Zuhal ERGEN \& Leman KILINÇKAYA 